\title{
Gambaran Kadar Asam Urat pada Pasien Infark Miokard Akut di RSUP Prof. Dr. R. D. Kandou Manado Periode September 2016 - Agustus 2017
}

\author{
${ }^{1}$ Bella M. T. Gonie \\ ${ }^{2}$ Frans E. N. Wantania \\ ${ }^{2}$ Octavianus R. H. Umboh
}
${ }^{1}$ Program Studi Pendidikan Dokter Fakultas Kedokteran Universitas Sam Ratulangi Manado
${ }^{2}$ Bagian Ilmu Penyakit Dalam Fakultas Kedokteran Universitas Sam Ratulangi Manado Email: gonie.bella@yahoo.co.id

\begin{abstract}
Acute myocardial infarction (AMI) is a cardiovascular disease that becomes one of the leading causes of death worldwide. Rupture of atherosclerotic plaque followed by thrombus formation and occlusion of coronary arteries causes an acute decrease in the blood supply to some parts of myocardium resulting in myocardial infarction, associated with inflammatory responses that may cause increased uric acid level. Patients of myocardial infarction accompanied by high uric acid level have higher mortality rate. This study was aimed to determine the description of uric acid level in patients with AMI at Prof. Dr. R. D. Kandou Hospital Manado. This was a retrospective descriptive study using medical record data of patients with AMI hospitalized at Prof. Dr. R. D. Kandou Hospital Manado in the period of September 2016 until August 2017. The results showed 92 AMI cases (60.1\%) who had elevated uric acid level. The majority of AMI cases were males (115 patients; 75.2\%), aged 51-60 years old, (52 patients; 34\%), Minahasan ethnic (138 cases; 90.2\%), and had no family history of high uric acid level (24 cases; $15.7 \%)$. Conclusion: The majority of the patients with AMI had elevated uric acid level.
\end{abstract}

Keywords: acute myocardial infarction, uric acid, inflammatory response.

\begin{abstract}
Abstrak: Infark miokard akut (IMA) merupakan penyakit kardiovaskular yang menjadi salah satu penyebab kematian di dunia. Pecahnya plak aterosklerosis dengan pembentukan trombus dan oklusi pembuluh koroner menyebabkan penurunan pasokan darah secara akut ke sebagian miokardium sehingga terjadi infark miokard, diikuti respon inflamasi yang menyebabkan asam urat meningkat. Pada pasien IMA dengan kadar asam urat tinggi dapat terjadi peningkatan angka kematian. Penelitian ini bertujuan untuk mengetahui gambaran kadar asam urat pada pasien IMA di RSUP Prof. Dr. R. D. Kandou Manado periode September 2016 sampai Agustus 2017. Jenis penelitian ialah deskriptif retrospektif menggunakan data rekam medik pasien IMA yang dirawat di RSUP Prof. Dr. R. D. Kandou Manado periode September 2016 sampai Agustus 2017. Hasil penelitian memperlihatkan 92 kasus IMA $(60,1 \%)$ memiliki kadar asam urat meningkat. Mayoritas kasus IMA berjenis kelamin laki-laki (115 pasien; 75,2\%), usia 51-60 tahun (52 pasien; 34\%), suku Minahasa (138 pasien; 90,2\%), dan tidak memiliki riwayat keluarga asam urat (24 pasien; 15,7\%). Simpulan: Sebagian besar pasien dengan IMA memiliki kadar asam urat yang meningkat.
\end{abstract}

Kata kunci: infark miokard akut, asam urat, respon inflamasi

Penyakit kardiovaskular merupakan penyebab utama kematian di dunia. ${ }^{1}$ Menurut American Heart Association (AHA) terdapat 81,1 juta kasus penyakit jantung di seluruh dunia dan diantaranya sebanyak 17,6 juta kasus merupakan penyakit jantung koroner (PJK) dengan manifestasi infark miokard akut (IMA). ${ }^{2}$ Infark miokard 
secara patologi didefinisikan sebagai kematian sel miokard karena iskemia berkepanjangan, yang merupakan manifestasi paling parah dari PJK. ${ }^{3}$

Di Indonesia pada tahun 2002 IMA merupakan penyebab kematian pertama dengan angka mortalitas 220.000 (14\%). ${ }^{4}$ Menurut hasil Riset Kesehatan Dasar (Riskesdas) tahun 2013 prevalensi penyakit IMA tertinggi yaitu Sulawesi Tengah 0,8\%, diikuti Sulawesi Utara, DKI Jakarta, dan Aceh, masing-masing $0,7 \% .^{5}$ Faktor risiko pada IMA dan PJK terdiri dari faktor risiko biologis yang tidak dapat diubah (usia, jenis kelamin, ras/etnis, dan riwayat keluarga) dan faktor risiko yang dapat diubah (merokok, alkohol, obesitas, dislipidemia, hipertensi, diabetes mellitus, dan asam urat). ${ }^{6,7}$

Asam urat adalah hasil akhir dari katabolisme nukleotida purin. Secara khusus, nukleotida purin berasal dari sintesis molekul endogen yaitu sintesis de novo dan kerusakan asam nukleat serta sumber eksogen yaitu asupan pencernaan. ${ }^{8}$ Dikatakan hiperurisemia bila serum asam urat minimal yaitu $6 \mathrm{mg} / \mathrm{dL}$ pada perempuan dan $7 \mathrm{mg} / \mathrm{dL}$ pada laki-laki. ${ }^{9}$

Penyakit asam urat di Indonesia terjadi pada usia yang muda, sekitar $32 \%$ pada laki-laki berusia kurang dari 34 tahun. Prevalensi pada kelompok usia muda antara 15-45 tahun juga terdapat di Bandungan, Jawa Tengah yaitu sebesar $0,8 \%$ meliputi laki-laki $1,7 \%$ dan perempuan $0,05 \%$. Berdasarkan suku, di Minahasa pada tahun 2003 tercatat proporsi kejadian artritis gout sebesar 29,2\% dan pada etnik tertentu di Ujung Pandang sekitar 50\% penderita ratarata telah menderita gout 6,5 tahun atau lebih setelah keadaan menjadi lebih parah. ${ }^{10,11}$ Penelitian yang dilakukan oleh Rotterdam menunjukkan bahwa konsentrasi asam urat serum yang tinggi terkait dengan risiko infark miokard. ${ }^{7,12}$ Asam urat mendorong perkembangan terjadinya aterosklerosis. ${ }^{13}$ Pecahnya plak aterosklerosis dengan pembentukan trombus dan oklusi pembuluh koroner menyebabkan penurunan pasokan darah secara akut ke sebagian miokardium sehingga terjadi infark mio- kard. ${ }^{14}$ Pada pasien infark miokard dengan kadar asam urat tinggi dapat terjadi peningkatan angka kematian. ${ }^{15}$

Penelitian ini bertujuan untuk mengetahui gambaran kadar asam urat pada pasien IMA di RSUP Prof. Dr. R. D. Kandou Manado periode September 2016 sampai Agustus.

\section{METODE PENELITIAN}

Jenis penelitian ini ialah deskriptif retrospektif menggunakan data rekam medik pasien IMA yang dirawat di RSUP Prof. Dr. R. D. Kandou Manado periode September 2016 sampai Agustus 2017. Pengambilan sampel penelitian menggunakan metode purposive sampling. Kriteria inklusi yaitu pasien infark miokard yang memiliki data lengkap dengan hasil pemeriksaan laboratorium asam urat, sedangkan kriteria eksklusi yaitu pasien yang mengonsumsi obat penurun kadar asam urat. Variabel penelitian ialah jenis kelamin, usia, suku, riwayat keluarga, dan kadar asam urat. Data yang dikumpulkan dari rekam medik pasien diolah dan disajikan dalam bentuk table dan diagram.

\section{HASIL PENELITIAN}

Dari total sampel yang diambil, sebanyak 115 orang $(75,2 \%)$ berjenis kelamin laki-laki dan 38 orang $(24,8 \%)$ berjenis kelamin perempuan (Gambar 1).

\section{Jenis Kelamin}

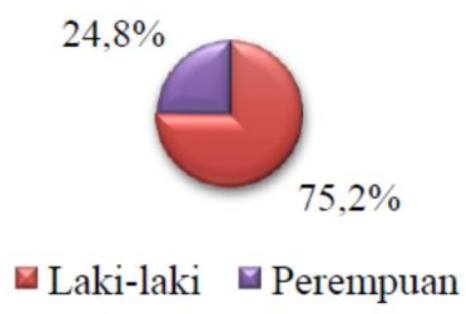

Gambar 1. Distribusi kasus IMA berdasarkan jenis kelamin

Pada prevalensi kasus IMA berdasarkan usia tidak didapatkan kasus IMA berusia $\leq 30$ tahun $(0 \%)$. Untuk kategori usia 31-40 tahun didapatkan sebanyak 7 kasus (4,6\%), 41-50 tahun sebanyak 26 
kasus (17\%), 51-60 tahun sebanyak 52 kasus (34\%), 61-70 tahun sebanyak 44 kasus (28,8\%), 71-80 tahun sebanyak 18 kasus $(11,8 \%)$, dan $>80$ tahun sebanyak 6 kasus $(3,9 \%)$. Usia terendah kasus IMA didapatkan terjadi pada usia 31 tahun dan usia tertinggi 88 tahun. (Tabel 1)

Tabel 1. Distribusi kasus IMA berdasarkan usia

\begin{tabular}{ccc}
\hline $\begin{array}{c}\text { Kategori usia } \\
\text { (tahun) }\end{array}$ & $\begin{array}{c}\text { Jumlah } \\
(\mathrm{n}=153)\end{array}$ & $\begin{array}{c}\text { Persentase } \\
(\%)\end{array}$ \\
\hline$\leq 30$ & 0 & $0 \%$ \\
$31-40$ & 7 & $4,6 \%$ \\
$41-50$ & 26 & $17 \%$ \\
$51-60$ & 52 & $34 \%$ \\
$61-70$ & 44 & $28,8 \%$ \\
$71-80$ & 18 & $11,8 \%$ \\
$>80$ & 6 & $3,9 \%$ \\
\hline
\end{tabular}

Distribusi kasus IMA mendapatkan pada kategori usia 31-40 tahun terdapat sebanyak 2 pasien perempuan $(5,3 \%)$ dan 5 pasien laki-laki (4,3\%); kategori usia 41-50 tahun terdapat sebanyak 6 pasien perempuan $(15,8 \%)$ dan 20 pasien laki-laki $(17,4 \%)$; kategori usia 51-60 tahun terdapat sebanyak 6 pasien perempuan $(15,8 \%)$ dan 46 pasien laki-laki (40\%); kategori usia 6170 tahun sebanyak 14 pasien perempuan $(36,8 \%)$ dan 30 pasien laki-laki $(26,1 \%)$; kategori usia 71-80 tahun sebanyak 6 pasien perempuan $(15,8 \%)$ dan 12 pasien laki-laki $(10,4 \%)$; kategori usia $>80$ tahun sebanyak 4 pasien perempuan $(10,5 \%)$ dan 2 pasien laki-laki (1,7\%) (Tabel 2).

Tabel 2. Distribusi kasus IMA berdasarkan usia dan jenis kelamin

\begin{tabular}{ccccc}
\hline \multirow{2}{*}{$\begin{array}{c}\text { Kategori } \\
\text { usia }\end{array}$} & \multicolumn{2}{c}{ Perempuan } & \multicolumn{2}{c}{ Laki-laki } \\
\cline { 2 - 5 } & $\begin{array}{c}\text { Jumlah } \\
(\mathrm{n}=38)\end{array}$ & $\begin{array}{c}\text { Persentase } \\
(\%)\end{array}$ & $\begin{array}{c}\text { Jumlah } \\
(\mathrm{n}=115)\end{array}$ & $\begin{array}{c}\text { Persentase } \\
(\%)\end{array}$ \\
\hline$\leq 30$ & 0 & $0 \%$ & 0 & $0 \%$ \\
$31-40$ & 2 & $5,3 \%$ & 5 & $4,3 \%$ \\
$41-50$ & 6 & $15,8 \%$ & 20 & $17,4 \%$ \\
$51-60$ & 6 & $15,8 \%$ & 46 & $40 \%$ \\
$61-70$ & 14 & $36,8 \%$ & 30 & $26,1 \%$ \\
$71-80$ & 6 & $15,8 \%$ & 12 & $10,4 \%$ \\
$>80$ & 4 & $10,5 \%$ & 2 & $1,7 \%$ \\
\hline
\end{tabular}

Prevalensi kasus IMA yang dirawat di RSUP Prof. Dr. R. D. Kandou Manado berdasarkan suku di Indonesia mendapatkan 2 kasus $(1,3 \%)$ dari suku Gorontalo, 1 kasus $(0,7 \%)$ dari suku Jawa, 138 kasus (90,2\%) dari suku Minahasa, 10 kasus (6,5\%) dari suku Mongondow, 1 kasus $(0,7 \%)$ dari suku Pasir Balik, dan 1 kasus $(0,7 \%)$ dari suku Talaud (Gambar 2).

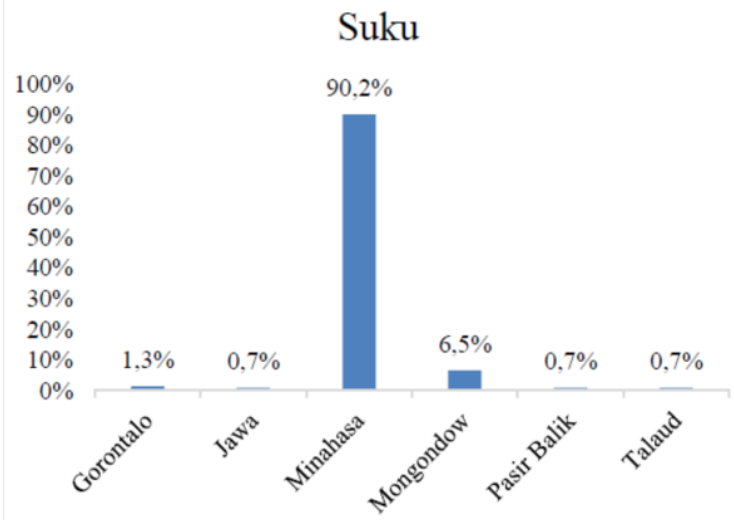

Gambar 2. Distribusi kasus IMA berdasarkan suku

Prevalensi kasus IMA berdasarkan riwayat keluarga yang memiliki kadar asam urat tinggi mendapatkan hasil 23 kasus (15\%), sedangkan yang tidak memiliki riwayat keluarga asam urat yaitu 24 kasus $(15,7 \%)$. Riwayat keluarga yang tidak diketahui didapatkan pada sebanyak 106 kasus $(69,3 \%)$ (Tabel 3).

Tabel 3. Distribusi kasus IMA berdasarkan riwayat keluarga

\begin{tabular}{ccc}
\hline $\begin{array}{c}\text { Riwayat } \\
\text { keluarga }\end{array}$ & $\begin{array}{c}\text { Jumlah } \\
(\mathbf{n = 1 5 3 )}\end{array}$ & $\begin{array}{c}\text { Persentase } \\
(\boldsymbol{\%})\end{array}$ \\
\hline Ya & 23 & $15 \%$ \\
Tidak & 24 & $15,7 \%$ \\
Tidak diketahui & 106 & $69,3 \%$ \\
\hline
\end{tabular}

Berdasarkan hasil laboratorium didapatkan kadar asam urat yang meningkat sebanyak 92 kasus $(60,1 \%)$ dan kadar asam urat normal sebanyak 61 kasus $(39,9 \%)$. Nilai kadar asam urat terendah pada perempuan yaitu $1,7 \mathrm{mg} / \mathrm{dL}$ dan tertinggi yaitu $16,1 \mathrm{mg} / \mathrm{dL}$ sedangkan pada laki-laki nilai kadar asam urat terendah yaitu 3,4 
$\mathrm{mg} / \mathrm{dL}$ dan tertinggi yaitu $17,3 \mathrm{mg} / \mathrm{dL}$ (Gambar 3).

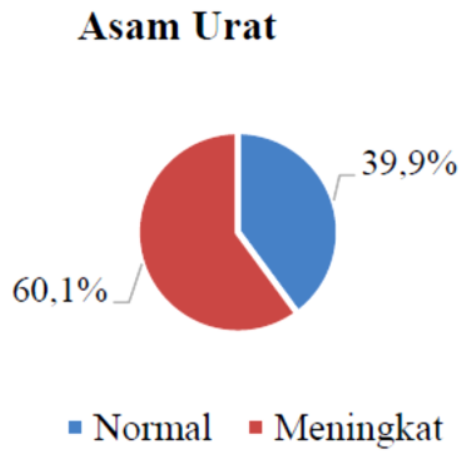

Gambar 3. Distribusi kasus IMA berdasarkan kadar asam urat

\section{BAHASAN}

Berdasarkan data yang diperoleh didapatkan 115 orang $(75,2 \%)$ laki-laki dan 38 orang $(24,8 \%)$ perempuan. Hal ini sesuai dengan penelitian oleh Maxwell et al. yang menyatakan laki-laki memiliki kadar asam urat yang lebih tinggi secara bermakna dibandingkan perempuan. ${ }^{1}$ Kadar asam urat lebih rendah pada perempuan karena saat premenopause estrogen bersifat urikosurik. ${ }^{14}$ Pada hasil penelitian berdasarkan usia tidak didapatkan kasus IMA berumur $\leq 30$ tahun $(0 \%)$. Prevalensi tertinggi terdapat pada kategori usia 51-60 tahun.

Berdasarkan jenis kelamin dida-patkan prevalensi tertinggi pada laki-laki yaitu kategori usia 51-60 tahun dan pada perempuan 61-70 tahun. Hasil penelitian ini selaras dengan penelitian Bhattacharya et al. ${ }^{16}$ yang mendapatkan kasus IMA tertinggi terjadi pada usia 50-59 tahun. Selain itu, Niskanen et al. ${ }^{17}$ menyatakan bahwa faktor risiko independen penyakit kardiovaskular terjadi saat pertengahan usia pada laki-laki. Haisl penelitian Sharaf et al $^{18}$ sesuai dengan penelitian ini dengan prevalensi tertinggi IMA pada perempuan yaitu usia 60 tahun ke atas.

Kejadian IMA dengan kadar asam urat tinggi berdasarkan suku didapatkan tertinggi pada suku Minahasa (90,2\%), selanjutnya suku Mongondow (6,5\%), suku Gorontalo (1,3\%), dan suku Jawa, Pasir Balik, serta Talaud (masing-masing 0,7\%).
Menurut penelitian oleh Rotty et al. ${ }^{19}$ prevalensi tertinggi terdapat di Minahasa. Hal ini disebabkan karena kebiasaan mengonsumsi daging dan alkohol yang merupakan bahan makanan tinggi purin.

Berdasarkan hasil penelitian, pasien IMA dengan kadar asam urat tinggi terdiri dari kelompok dengan riwayat keluarga asam urat $(15 \%)$ dan yang tidak mempunyai riwayat keluarga asam urat $(15,7 \%)$. Hal ini sesuai dengan penelitian oleh Setyo et al. ${ }^{20}$ yang mendapatkan sebagian besar $(57,5 \%)$ tidak mempunyai riwayat keluarga yang menderita penyakit asam urat.

Berdasarkan data yang diperoleh sebanyak 92 kasus $(60,1 \%)$ didiagnosis IMA dengan kadar asam urat yang meningkat dan 61 kasus $(39,9 \%)$ dengan kadar asam urat normal. Kadar asam urat yang meningkat terjadi sebagai hasil peningkatan produksi asam urat, ketidakseimbangan eksresi asam urat oleh ginjal, atau kombinasi keduanya. ${ }^{21}$ Hasil penelitian ini didukung oleh penelitian Strasak et al. ${ }^{14}$ yang melaporkan bahwa hasil penelitian kohort yang dilakukan di Austria mendapatkan hubungan antara peningkatan asam urat dan kejadian infark miokard yaitu 5 kali lipat dari kasus kontrol.

Limitasi penelitian ini yaitu keterbatasan data rekam medik yang diperoleh karena data yang tidak lengkap dan tidak ditemukan (hilang).

\section{SIMPULAN}

Berdasarkan hasil penelitian ini dapat disimpulkan bahwa pasien IMA dengan kadar asam urat meningkat lebih banyak dibandingkan yang dengan kadar asam urat normal. Distribusi kasus IMA lebih sering terjadi pada laki-laki, dan kategori usia pada perempuan yaitu 61-70 tahun sedangkan pada laki-laki 51-60 tahun.

\section{DAFTAR PUSTAKA}

1. Reddy KVC, Ghanekar J. Prognostic role of SUA in critically ill patients with non ST elevation acute myocardial infarction. JCvD. 2015;3(3):337-46.

2. Budiman, Sihombing R, Pradina $P$. Hubungan dislipidemia, hipertensi dan 
diabetes melitus dengan infark miokard akut. JKMA. 2015;10(1):34.

3. Mozaffarian, Benjamin D, Go EJ, Arnett AS, Blaha DK, Cushman MJ, et al. Heart disease and stroke statistics2015 Update: A report from the american heart association. Circulation. 2015;131:29-322.

4. Dwiputiyanti S. Infark miokard akut [cited 2017 Aug 29]. Avilable from: URL: HYPERLILNK https://www.academia. edu/8389060/AMI_ROES_OK

5. Kemenkes RI. 2013. Riset Kesehatan Dasar 2013. [pdf] Jakarta: Badan Penelitian dan Pengembangan Kesehatan. [cited 2017 Aug 30].

6. Huma S, Tariq R, Amin F, Mahmood KT. Modifiable and non-modifiable predisposing risk factors of myocardial infarction - a review. J Pharm Sci \& Res. 2012;4(1):1649-53..

7. Kuo CF, Yu KH, See LC, Chou IJ, Ko YS, Chang HC, et al. Risk of myocardial infarction among patients with gout: a nationwide population-based study. Rheumatology. 2013;52(1):111-7.

8. Grassi D, Ferri L, Desideri G, Giosia PD, Cheli P, Pinto RD, et al. Chronic hyperuricemia, uric acid deposit and cardiovascular risk. Curr Pharm Des. 2013;19(13): 2432-8.

9. Mehrpooya M, Larti F, Nozari Y, Sattarzadeh-Badkoobeh R, ZandParsa A, Zebardast J, et al. Study of serum uric acid levels in myocardial infarction and its association with killip class. Acta Medica Iranica. 2017;55(2): 97-102.

10. Hidayat R. Gout dan hiperurisemia. Medicinus. 2009;22:47-50.

11. Dinas Kesehatan Propinsi Jawa Tengah, Survailence Penyakit Tidak Menular pada Puskesmas dan Rumah Sakit di Jawa Tengah, Semarang, 2007.

12. Memon AG, Shah MI, Kumar S. Uric acid levels association with different risk factors of acute MI. J Cardiovasc Dis
Diagn. 2016;4:253.

13. Chen L, Li X, Qiao W, Ying Z, Qin Y, Wang Y, et al. Serum uric acid in patients with acute ST-elevation myocardial infarction. WJEM. 2012; 3(1):35-39.

14. Ghanekar J, Mishra G, Reddy KVC. Serum uric acid as cardiovascular disease marker: premises and promises. Int J Sci. 2014;3:18-27

15. Hajizadeh R, Ghaffari $S$, Salehi R, Mazani S, Aghavali S. Association of serum uric acid level with mortality and morbidity of patients with acute STelevation myocardial infarction. $\mathbf{J}$ Cardiovasc Thorac Res. 2016;8(2):5660.

16. Bhattacharya PK, Agarwal M, Gautom D, Saikia H. Role of serum uric acid level in predicting outcome in acute myocardial infarction. National $\mathrm{J}$ Lab Medicine. 2016;5(4):18-22.

17. Jin M, Yang F, Yang I, Yin Y, Luo JJ, Wang $\mathbf{H}$, et al. Uric acid, hyperuricemia and vascular diseases. Front Biosci. 2012;17:656-69.

18. Sharaf El Din UAA, Salem MM, Abdulazim DO. Uric acid in the pathogenesis of metabolic, renal, and cardiovascular review. J Advanced Research. 2017;8(5):537-48.

19. Rotty LWA. Gambaran asam urat pada suku Minahasa usia dewasa muda [Tesis]. Manado: Bagian Ilmu Penyakit Dalam Fakultas Kedokteran Universitas Sam Ratulangi; 1999.

20. Setyo ATW, Tjahjono HD. Faktor-faktor yang memengaruhi kadar asam urat (gout) pada laki-laki dewasa di RT 04 RW 03 Simomulyo Baru Surabaya [Skripsi]. Surabaya; 2014. Available from: download.portalgaruda.org...\% 20KADAR\%20ASAM\%20URAT\%20

21. Maiuolo J, Oppedisano F, Gratteri S, Muscoli C, Mollace V. Regulation of uric acid metabolism and excretion. Int J Cardiol. 2016;213:8-14. 